\title{
Genital Infection by Gardnerella vaginalis and Candida spp. among Women in Nova Iguaçu City, Rio de Janeiro Province, Brazil
}

\author{
Pedro Henrique Siqueira Lopes ${ }^{1}$, Victoria Luiza Pacini1 ${ }^{1}$, Antonio Neres Norberge,3 \\ ${ }^{1}$ Medicine Students of Souza Marques Medicine School-FTESM, Rio de Janeiro, Brazil \\ ${ }^{2}$ Host-Pathogen Interaction Department, Souza Marques Medicine School, Souza Marques Technic-Educational \\ Foundation-FTESM, UNIABEU/PROBIN University Center, Rio de Janeiro, Brazil \\ ${ }^{3}$ Medicine School of Manhuaçu Management Sciences Faculty_FACIG, Manhuaçu, Brazil \\ Email: antonionorberg@gmail.com
}

How to cite this paper: Lopes, P.H.S., Pacini, V.L. and Norberg, A.N. (2017) Genital Infection by Gardnerella vaginalis and Candida spp. among Women in Nova Iguaçu City, Rio de Janeiro Province, Brazil. Open Access Library Journal, 4: e3366. https://doi.org/10.4236/oalib.1103366

Received: January 10, 2017

Accepted: March 3, 2017

Published: March 6, 2017

Copyright ( 2017 by authors and Open Access Library Inc.

This work is licensed under the Creative Commons Attribution International License (CC BY 4.0).

http://creativecommons.org/licenses/by/4.0/

\begin{abstract}
Vaginitis is the most common infectious disease diagnosed among women attended at gynecological outpatient clinics in the Primary Care Service. The aim of this research is to investigate the incidence of vaginitis caused by Gardnerella vaginalis and Candida spp. in women attended at the gynecological outpatient clinic of Dr. Vanderlei Pacini Gynecological Clinic in the city of Nova Iguaçu, Rio de Janeiro Province. The studied population consisted of 386 women. For the sample of the vaginal secretion, we use disposable speculum and sterile swabs were used. Material was removed from lateral vaginal walls and recto-uterine pouch. Two slides were prepared and sent to clinical pathology and histocytopathology laboratories. The preparations were stained with Gram and Papanicolaou staining methods, and examined under a light microscope with a $1000 \times$ magnification. Among the 386 examined women, 82 (21.24\%) cases of infection by one of the investigated microorganisms were diagnosed: 60 of Gardnerela vaginalis $(\mathrm{CP}=15.54 \%)$ and 22 of Candida spp. $(\mathrm{CP}=5.44 \%)$. Infections and complications caused by $G$. vaginalis and Candida spp. constitute a serious health problem for women, which should carry out periodic examinations to safeguard gynecological health.
\end{abstract}

\section{Subject Areas}

Epidemiology, Gynecology \& Obstetrics, Infectious Diseases, Public Health, Women's Health

\section{Keywords}

Gardnerella vaginalis, Candidiasis, Vulvovaginitis 


\section{Introduction}

Microbial aggressions of the vaginal and vulvar cavity are frequent and often caused by microbial elements like bacteria, virus, fungi and protozoa. Infections caused by these microorganisms are much more frequent in patients with low socioeconomic conditions, promiscuous and active sexual life people. Infectious vaginitis is the most common infectious disease diagnosed among women attended at gynecological outpatient clinics in primary health care services. Lactobacillus acidophilus is one of the constituents of the normal vaginal microbiota, constituting the bacterial flora of Doderlein, which acts as a protective chemical barrier to infections, turning difficult the implantation of certain pathogens. Infections usually occur as a result of an environmental imbalance in the vaginal ecosystem or due to infection caused by a sexually transmitted microorganism. Nowadays there is an especial attention to the relation between infections or abnormal changes associated with the development of the microbiota constituted by anaerobic bacteria, mainly Gardnerella vaginalis and Mobiluncus spp. These bacteria are sexually transmitted and blamed for fetid leukorrhea, pelvic inflammation and even abortus. In some cases it can cause balanitis [1] [2] [3].

Bacterial vaginosis was described by Gardner and Dukes [4] as a non-specific vaginitis characterized by foul-smelling vaginal discharge with gray color, $\mathrm{pH}$ above normal, with Gardnerella vaginalis as its main etiological agent. In pregnant women, they may cause unfavorable effects to pregnancy, including endometritis, pelvic and inflammatory diseases, premature birth and postpartum endometritis [5] [6]. There is still a possibility that the bacteria which cause vaginosis may ascend to the female tract through the cervix and cause infection to the concept [7] [8]. The bacterial flora that causes vaginosis is believed to produce toxins that make some women more susceptible to start a cascade of cytokines and prostaglandins that may trigger preterm labor [6]. The possibility of protease production by these microorganisms that would cause rupture of the membranes is also allowed, which would initiate premature labor [9].

Candida species are associated with vulvovaginitis, especially at certain stages of the menstrual cycle or when the patient was submitted to a prolonged antibiotic therapy, often presenting a characteristic flow like a "coagulated milk", accompanied by pruritus, dysuria and stiffening of the vaginal mucosa and vulvar epithelium. It is estimated that up to $75 \%$ of sexually active women develop candidiasis at least once during their life and between $5 \%$ and $10 \%$ of them present the recurrent form, characterized by three or more episodes in a year [1].

Considering the importance of these microorganisms to the gynecological pathology, this study aimed to investigate the incidence of vaginitis caused by Gardnerella vaginalis and Candida spp in women attended at the gynecological outpatient clinic Dr. Vanderlei Pacini in the city of Nova Iguaçu, Rio de Janeiro Province, Brazil.

\section{Methods}

The design of this research is observational, cross-sectional and retrospective. 
The research was conducted following data obtained from the medical records of the women attended at the Gynecology Clinic Dr. Vanderlei Pacini, in the city of Nova Iguaçu, Rio de Janeiro Province. 386 medical records from January to December 2015 were evaluated, each one constituting a sample unit. The inclusion criteria were: to live in Nova Iguaçu city, not to be in the menstrual phase and have active sexual life. Although being in the inclusion criteria, the following exclusion criteria were considered: women with local or systemic treatment for vaginitis or previous history of diseases associated with immunodeficiency. Express permission was requested to the patients for publication of the data without personal identification in a scientific paper.

To collect samples of vaginal secretion, material was obtained from the lateral vaginal walls and recto-uterine pouch. Two slides were prepared and sent to clinical pathology and histocytopathology laboratories. The preparations were stained by Gram and Papanicolaou staining methods and examined under a light microscope at $1000 \mathrm{X}$ magnification.

\section{Results}

$82(21.24 \%)$ of the 386 women examined were infected by one of the two microorganisms, which 60 were diagnosed with infection by $G$. vaginalis (Table 1), with a prevalence coefficient (PC) of $15.54 \%$ and 22 with Candida spp. (PC = $5.44 \%)$. The prevalence coefficients for infections by the two microorganisms indicates that the highest rate is in the 15 - 24 age group and 25 to 34, showing the age class that should be receive more attention (Table 1 ).

\section{Discussion}

One of the most common causes of vaginal infection in women of childbearing age is bacterial vaginosis (BV). At the puberty, high levels of estrogen are produced, both plasmatic as from tissue origin, that raises the levels of this hormone in epithelial cells. The metabolism of glycogen by some species of the genus Lactobacillus produces lactic acid, which reduces the normal $\mathrm{pH}$ of the vagina, which varies between 3.8 and 4.2. This rangerange is is unfit for the multiplication of Gardnerella vaginalis and other anaerobic microorganisms. Also some

Table 1. Number of diagnosed cases of vulvovaginitis, with identification of microbial agents, among 386 women examined by staining and Gram and Papanicolaou methods, in the city of Nova Iguaçu, from January to December 2015, with a prevalence coefficient (PC) of species and for age group.

\begin{tabular}{ccc}
\hline Age class (years) & Gardnerella vaginalis $\left(\mathrm{N}^{\circ}\right)[\mathrm{PC} \%]$ & Candida spp. $\left.^{\circ} \mathrm{N}^{\circ}\right)[\mathrm{PC} \%]$ \\
\hline $15_{\mathrm{H}} 24$ & $(11)[16.17 \%]$ & $(8)[11.76 \%]$ \\
$25_{\mathrm{H}} 34$ & $(19)[14.72 \%]$ & $(11)[8.52 \%]$ \\
$35_{\mathrm{H}} 44$ & $(20)[19.60 \%]$ & $(0)[0 \%]$ \\
$\geq 45$ & $(10)[11.49 \%]$ & $(2)[2.29 \%]$ \\
Total & $(60)[15.54 \%]$ & $(21)[5.44 \%]$ \\
\hline
\end{tabular}

Source: Dr. Vanderlei Pacini Gynecological Clinic. 
species of the genus Lactobacillus are toxins producers such as hydrogen peroxide, which inhibits the multiplication of other species of pathogenic microorganisms. Bacterial vaginosis occurs when there is a reduction in the number of Lactobacillus spp. and consequently the decrease of lactic acid production, resulting in elevation of the $\mathrm{pH}$. This increase contributes to the growth of Gardnerella vaginalis as well as other anaerobic microorganisms. With the increase of these microorganisms, the production of organic acids as so of amines by the degradation of proteins takes place. This combination causes exfoliation of the epithelial cells of the vaginal wall, resulting in the formation of non-inflammatory exudate. As causes of the decrease of the beneficial flora constituted by Lactobacillus spp are the antibiotic therapy, vaginal showers and sexually transmitted diseases [8] [10] [11].

Canales and Castillo [12] accounted the prevalence of etiological agents of vaginal infections in pregnant and non-pregnant women in the city of Talca, Chile. They collected vaginal secretion from 176 volunteers, prepared smears stained by the Gram method for direct bacterioscopy and seeded in artificial culture media to identify microbial agents. Gardnerella vaginalis $18.18 \%$ and Candida albicans (11.6\%) were isolated. The authors emphasized that the highest prevalence of vaginal infection was found among the age groups between 21 and 30 years, since it maintains partial identity with the findings of now, mainly because the age groups worked were not the same. The authors emphasizes that the highest prevalence of vaginal infection was found among the age groups between 21 and 30 years, which maintains partial identity with our results, mainly because the range of the age groups were not the same.

A research to determine the prevalence of vaginitis and vaginosis among police officers from the Province of Ica, Peru, was performed by Hernández-Ríos [13]. The author examined vaginal secretion of 80 women through Giemsa staining method and found positivity in $77.5 \%$ of the samples. In $27.5 \%$ of the women found Trichomonas vaginalis, $12.5 \%$ Gardnerella vaginalis, and $11.2 \%$ Candida spp, higher incidence than we found in our research related to vaginitis by $G$. vaginalis. The author considered as possible predisposing factors was the fact that these women work standing up for hours controlling the traffic, the use of uniforms made with synthetic material, the heat of the city that registers high temperatures and the lack of knowledge about vaginal infections by the affected women.

The prevalence of Trichomonas vaginalis, Candida albicans and Gardnerella vaginalis in women without clinical symptoms of vaginitis treated at family clinics of the province of Mayabeque, Cuba, was investigated by Rodrigues et al. [1] $100(55.87 \%)$ of 127 samples were negative and 79 were positive (44.13\%). Candidiasis was the most frequent infection observed (25.14\%) corresponding to $56.96 \%$ of the total positive diagnostics performed. Bacterial vaginosis was diagnosed in 33 (15.44\%) of the women examined, and trichomoniasis was detected in only five patients $(2.79 \%)$. The authors concluded that there is a significant contingent of women with vaginal infections despite being asymptomatic. It is 
possible that similar situation happens in the city of Nova Iguaçu, which demands more investigations.

Sexually transmitted infections were studied by Garaycochea et al. [14] in a penitentiary establishment in Lima, Peru. A total of 168 samples of cervicovaginal secretion were analyzed and the most prevalent etiological agents were Chlamydia trachomatis $(42.3 \%), G$. vaginalis $(24.4 \%)$ and $T$. vaginalis $(10.11 \%)$. The authors concluded that there is a high prevalence of sexually transmitted infections among prisoners of the Chorillus I penitentiary complex in the city of Lima and suggested to the health authorities the need to implement a female prison health assistance program to control the treatment of sexually transmitted diseases.

Vasconcelos et al. [15] performed a documentary and retrospective research involving women attended at family health centers in the city of Fortaleza, Ceará, Brazil, and identified in colpocytological examinations vaginal affections suggestives of an inflammatory process were caused by G. vaginalis $(25.3 \%)$, Candida albicans (10.2\%) and $T$. vaginalis (3.1\%), with a higher incidence than we found in the city of Nova Iguaçu. These authors commented that in $66.7 \%$ of reports of cervical intraepithelial neoplasia type I/HPV, G. vaginalis was present, suggesting a significant association between Human Papilloma Virus DNA and bacterial vaginosis microbiota. Following this warning association, it is important to consider the opposition of Andrade et al. [3] when they explains the lack of scientific researches focusing on vaginal infections, In this way, new research should be encouraged to collaborate with the scientific community in order to provide knowledge and guide professional practices.

\section{Conclusion}

From the analysis of the results, the conclusion is that the infections and complications caused by Gardnerella vaginalis and Candida spp. are a serious health problem in the city of Nova Iguaçu. We believe that all women should perform periodic controls with the gynecologist with inspection of vaginal secretions in order to obtain early diagnosis and specific treatment for the diagnosed etiological agents. Further attention is advised for adolescent women beginning sexual activity, and those over the age of 45 who may be neglecting gynecological health actions.

\section{Acknowledgements}

The authors would like to thank the Dr. Vanderlei Pacini Gynecological Clinic for help with patient data and declarations of agreement, clinical exams and material.

\section{References}

[1] Rodrigues, M.L., Reyes, O.G., Miranda, L.S. and Limia, O.C. (2014) Prevalencia de Trichomonas vaginalis, Candida albicans y Gardnerella vaginalis en mujeres sin sintomas de vaginitis. Revista Ciencia Médica La Habana, 20, 164-174. 
http://new.medigraphic.com/cgi-bin/resumen.cgi?IDARTICULO=56091

[2] Brasileiro Filho, G. (2014) Bogliolo Patologia. Guanabara Koogan, Rio de Janeiro.

[3] Andrade, S.S.C., Silva, F.M.C., Oliveira, S.H.S., Leite, K.N.S., et al. (2014) Agentes microbiológicos de vulvovaginites identificados pelo Papanicolaou. Revista de Enfermagem da UFPE, 8, 338-345.

http://www.repositorio.ufc.br/handle/riufc/8868

[4] Gardner, H.L. and Dukes, C.D. (1955) Haemophilus vaginalis and Vaginitis: A Newby Defined Specific Infection Previously Classified Non-Specific Vaginitis. American Journal of Obstetrics and Gynecology, 69, 962-976. https://doi.org/10.1016/0002-9378(55)90095-8

[5] Oliveira, E.H. and Soares, L.F. (2007) Prevalência de vaginites infecciosas através da citologia clínica: Um estudo no laboratório central de saúde pública no Piauí. Revista Brasileira de Análises Clínicas, 39, 33-35.

[6] Morris, M., Nicoll, A., Sims, I., Wilson, J., et al. (2001) Bacterial Vaginosis: A Public Health Review. British Journal of Obstetrics and Gynaecology, 108, 439-450.

http://onlinelibrary.wiley.com/doi/10.1111/j.1471-0528.2001.00124.x/full https://doi.org/10.1016/S0306-5456(00)00124-8

[7] Bonfati, G. and Gonçalves, T.L. (2010) Prevalência de Gardnerella vaginalis, Candida spp e Trichomonas vaginalis em exames citopatológicos de gestantes atendidas no Hospital de Santa Maria, RS. Revista de Saúde Santa Maria, 36, 37-46.

https://periodicos.ufsm.br/revistasaude/article/download/2343/1553

https://doi.org/10.5902/223658342343

[8] Hay, P.E. (2004) Bacterial Vaginosis and Miscarriage. Current Opinion on Infectious Diseases, 17, 41-44.

http://journals.lww.com/co-infectiousdiseases/pages/articleviewer.aspx?year=2004\& issue $=02000$ \&article $=00008 \&$ type $=$ abstract https://doi.org/10.1097/00001432-200402000-00008

[9] Martins, J. and Eschenmach, D.A. (1990) The Role of Bacterial Vaginosis as a Cause of Ammiotic Fluid Infection, Chorioaminiontis and Prematury-A Review. Archives of Gynecology and Obstetrics, 247, 1-13. https://doi.org/10.1007/BF02390649

[10] Nugent. R.P., Krohn, M.A. and Hillier, S.L. (1991) Reliability of Diagnosing Bacterial Vaginosis Is Improved by a Standardized Method of Gram Stain Interpretation. Journal of Clinical Microbiology, 29, 297-301. https://www.researchgate.net/publication/21448509_Reliability_of_diagnosing_bact eri-

al_vaginosis_is_improved_by_a_standardized_method_of_gram_stain_interpretati on

[11] Mota, D.A., Monteiro, C.A., Monteiro, S.G. and Figueiredo, P.M.S. (2012) Prevalência de vaginose bacteriana em pacientes que realizaram bacterioscopia de secreção vaginal em laboratório de saúde pública. Revista da Sociedade Brasileira de Clínica Médica, 10, 15-18.

http://pesquisa.bvsalud.org/ghl/resource/en/lil-612005

[12] Canales, V. and Castillo, J.A. (2012) Estudio microbiológico de flunjo vaginal en pacientes tratadas en consultório norte Dr. José Astaburuaga y en centro de Salud La Florida de la ciudad de Talca. Universidad de Talca, Escuela de Tecnología Médica, Talca.

http://dspace.utalca.cl/handle/1950/9377

[13] Hernández-Ríos, E. (2011) Prevalencia de vaginites y vaginoses bacterianas en personal policial de la provincia de Ica, Peru. Revista Médica Panacea, 1, 40-43. http://www.imbiomed.com.mx/1/1/articulos.php?method=showDetail\&id_articulo 
=93135\&id_seccion=5320\&id_ejemplar=9128\&id_revista $=343$

[14] Garaycochea, M.C., Pino, R., Cháves, I., Portillo, J.L., et al. (2013) Infecciones de transmisión sexual en mujeres de un establecimiento penitenciario de Lima, Peru. Medicina Experimental y Salud Pública, 30, 23-427.

http://www.scielo.org.pe/scielo.php?script=sci_arttext\&pid=S1726-46342013000300 008\&lng=es\&nrm=iso

[15] Vasconcelos, C.T.M., Neto, J.A.V., Castelo, A.R.P., Medeiros, F.C., et al. (2010) Analysis of Coverage and of the Pap Test Exams Not Retired of a Basic Health Unit. Revista de Enfermagem da USP, 44, 323-328.

http://www.scielo.br/scielo.php?script=sci_arttext\&pid=S0080-62342010000200012 \&lng=en\&nrm=iso

Submit or recommend next manuscript to OALib Journal and we will provide best service for you:

- Publication frequency: Monthly

- 9 subject areas of science, technology and medicine

- Fair and rigorous peer-review system

- Fast publication process

- Article promotion in various social networking sites (LinkedIn, Facebook, Twitter, etc.)

- Maximum dissemination of your research work

Submit Your Paper Online: Click Here to Submit

Or Contact service@oalib.com 